Working Paper n. 14 - 2009

\title{
STRUCTURAL FUNDS AND ECONOMIC DIVIDE IN ITALY
}

\section{Francesco Aiello}

Dipartimento di Economia e Statistica Università della Calabria Ponte Pietro Bucci, Cubo 1/C

Tel.: +390984 492440

Fax: +390984 492421

e-mail: f.aiello@unical.it

\section{Valeria Pupo}

Dipartimento di Economia e Statistica Università della Calabria Ponte Pietro Bucci, Cubo 1/C Tel.: +390984 492456 Fax: +390984 492421 e-mail: v.pupo@unical.it

\section{Ottobre 2009}

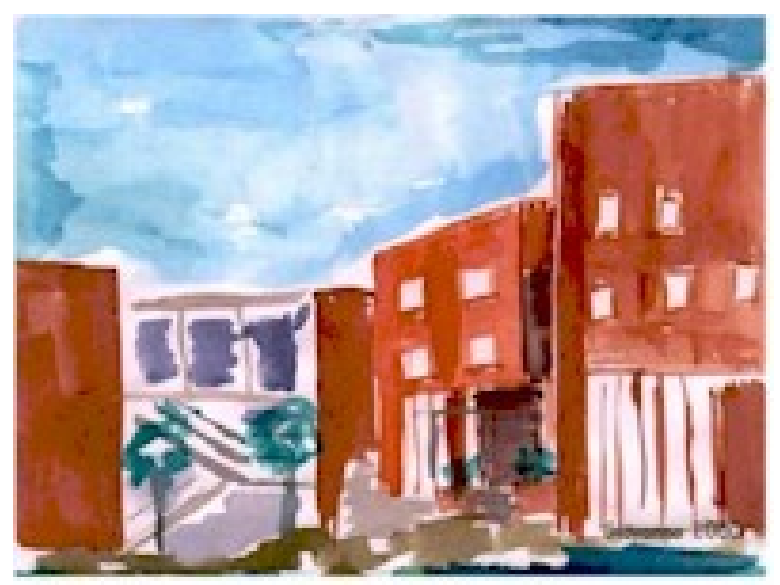

Pubblicazione depositata ai sensi della L. 106 del 15-4-2004 e del DPR 252 del 3-5-2006 


\title{
Structural Funds and Economic Divide in Italy*
}

\author{
Aiello Francesco, Pupo Valeria \\ [f.aiello@unical.it; v.pupo@unical.it] \\ University of Calabria \\ Department of Economics and Statistics \\ www.ecostat.unical.it \\ 87030 Arcavacata di Rende (CS), Italy
}

\begin{abstract}
This paper aims to provide a contribution to the debate on the effectiveness of cohesion policies in Italy. The focus is on the territorial effects of EU spending from 1996 to 2007. The empirical analysis is based on the estimate of an expanded neoclassical growth model in which the Structural Funds are one of the variables that explain the convergence across Italian regions. Using panel data and a dynamic panel estimator we find that the Structural Funds, even having had a greater impact in the South compared to the Centre-North, have not contributed to reduce the economic divide in Italy.
\end{abstract}

Keywords: $\quad$ Structural Funds, Regional Policy, Economic Divide in Italy

Codes JEL: H50, R58, O47

\section{Introduction}

This article contributes to the debate on the impact of the Structural Funds in Italy and concentrates on the territorial effects of the European Union spending from 1996 to 2007. This type of evaluation is crucial for Italy, in that the presence of a substantial economic divide is a phenomenon that for decades has characterised the economic model of this country.

An indication of the persistence in economic discrepancies in Italy is obtained by comparing the regional GDP per-capita in the years 1980-1981 and 2006-2007 (ISTAT, 2005; 2008). It can be noticed that during these last 25 years no variation is found in the regional order: the regions in which the GDP per-capita was, at the beginning of the period, below the national average occupy the same position at the end of the period (the correlation between the series of regional GDP per-capita at the beginning and the end of the period is 0.95). This persistence in the economic divide is observable even if different time periods are considered. For instance, when considering the years 1996-2007, which are the ones chosen here to evaluate the role of Structural Funds, it emerges that at the end of the period the income discrepancy is still very large: in 2006-2007 the income of an inhabitant of the richest region (Valley d'Aosta) is, on average, 2.6 times higher than that of an inhabitant of the poorest region (Calabria).

\footnotetext{
* Although the paper is the result of close collaboration among the authors, sections 1, 2 and 3 were written by Valeria Pupo and sections 4 and 5 by Francesco Aiello.
} 
The persistency of such divide, despite the amount of EU resources destined to the underdeveloped areas of the country, makes the question of the effectiveness of these policies more poignant. The evaluation of the effects of the cohesion policy is a particularly relevant issue if one thinks that the Structural Funds represent a significant quota of the public transfer payments in favour of Southern Italian regions.

In this work, an empirical analysis for the period 1996-2007 is realised by estimating a panel data growth model in which the dependent variable is the annual growth rate of GDP percapita, or of the labour productivity, and the Structural Funds are used as a further explanatory variable of the convergence equation. Estimations are carried out by using the Kiviet and the GMM-SYS estimators and, in this sense, this is the only study, to our knowledge, that uses in this field of research a dynamic panel estimators which allows us to account for the non-observable regional heterogeneity, the small-sample bias and for the possible endogeneity of Structural Funds and other regressors in order to obtain consistent estimates.

The work is organized as follows. Section 2 briefly reviews the related literature. Section 3 proposes an analysis of the territorial distribution of the Structural Funds and of the ability of the Italian regions to manage their spending. Section 4 evaluates the results of the structural policies on the convergence process across Italian regions. These are followed by some concluding considerations.

\section{The impact of structural funds: a brief literature overview}

Although a vast literature has analysed the convergence processes in Europe, there are few empirical verifications of the impact of the Structural Funds on the regional economic discrepancies. Substantially, two approaches are used. The first one aims to estimate the impact of the Structural Funds using model based on labour demand and aggregate production functions (de la Fuente, 2002; Percoco, 2005). These models allow the gathering of an indirect impact produced by the European regional policies on the convergence process. The second approach aims to directly analyse the contribution of the Structural Funds on economic convergence through the estimation of conditional convergence equations (Boldrin and Canova, 2001; Garcia Solanes and Marìa-Dolores, 2002; Cappelen et al, 2003; Ederveen et al, 2002; PuigcerverPeňalver, 2007). Irrespective of the methodology, empirical evidence from these studies does not allow one to draw clear indications of the role of these policies. A critical point of view on the effectiveness of the funds is expressed in the works of Boldrin and Canova (2001), ISAE (2001), Ederveen et al (2002), Midelfart-Knarvik and Overman (2002), Cappellen et al (2001), Dall'erba and Le Gallo (2008) which substantially underline the redistribution effect of the funds in Europe. More optimistic results are obtained in the studies of de la Fuente (2002) and of Garcia Solanes and Marì-Dolores (2002). An exhaustive review on the effects determined by the Structural Funds is provided by Pupo (2004).

The conflicting results which the empirical literature reaches can partly depend on some problems linked to the nature of the data used in the analyses. It is necessary to underline that there is no a complete dataset of EU funds at a regional level neither from the territorial point of view (because of the changes of the regional administrative borders of some countries and the various enlargements of the EU) nor from the financial point of view (the data related to EU spending are classified on a regional base and for typology of intervention only from the mid 1990s). Also, no study uses the amount of Structural Funds spent by each region but all the related literature refers to the programmed or committed amounts (Coppola and Destefanis, 2007; 
Garcìa Solanes and Marìa-Dolores, 2002; de la Fuente, 2002). Other critical aspects concern the methodology used to face the problem of the limited size of the sample, of the potential endogenous nature of the regressors, of the non observable heterogeneity across regions, as well as of the effects of the business cycle. The presence of these issues could have influenced the measurement of the impact of the Structural Funds and explain, at least partly, the conflicting results reached by the empirical analyses.

This work tries to overcome some of these critical aspects, since, for example, it considers only the Italian regions in which the administrative borders have not changed over time, it uses the amount spent and not only the resources committed and adopts a methodology that deals with the above mentioned econometric issues. Also, it proposes the first empirical evidence on the territorial effects of EU spending and, in this sense, it contributes to enriching the literature that in Italy has dealt with the impact of the Structural Funds, so far limited to the works of Coppola and Destefanis (2007), Loddo (2006) and Percoco (2005).

Coppola and Destefanis (2007) appraise the effects of Structural Funds on the convergence across Italian regions over the period 1989-2003 using a parametric approach that permits the identification the contribution of capital deepening and of total factor productivity (TFP) to the growth of GDP per-capita. The results show that the Structural Funds have had a weak, but significant, impact on capital accumulation and on the components of TFP growth, while having a weak impact on employment. Percoco (2005) estimates a supply-side model using a panel of regional data over the period 1970-94. He finds a high volatility in the level of growth rates induced by Structural Funds expenditure allocated in six Italian Southern regions (Molise, Campania, Puglia, Basilicata, Calabria and Sardinia) over the period 1994-1999. Such differences are attributed to the different behaviour of regional administrations in allocating the resources among the productive factors: the regions (Puglia, Basilicata and Sardinia) that have allocated the funds in favour of production inputs with a high marginal productivity are those that have obtained the best performance in terms of increase of output. Finally, Loddo (2006) estimates a model of regional growth using a balanced panel of annual data from 1994 to 2004 and finds that the impact of the cohesion policies is positive.

\section{Structural funds in Italy}

\subsection{Territorial distribution of the structural funds}

A useful indicator to appraise the intensity of state intervention aimed at fostering economic growth is the capital account public expenditure (investments expenditure and capital account transfers) that represents a relevant component of the total productive capital stock and, therefore, constitutes a key element for the growth of the Italian regions. ${ }^{1}$

The distribution of the investments by geographical area is consistent with the objectives of territorial rebalancing, since it is in the regions of the Mezzogiorno ${ }^{2}$ that the greatest spending is concentrated in respect to both the regional GDP and to the population. Accordingly, this allocation of funds produces a significant re-distributional effect. In fact, in the period 1996-

\footnotetext{
${ }^{1}$ From an empirical point of view, a review of the effect of public investments on growth is contained in Romp and De Haan (2007).

2 The Regions of the Mezzogiorno are Abruzzo, Molise, Puglia, Campania, Basilicata, Calabria, Sicily and Sardinia.
} 
2006, the annual per-capita spending is equal to 876 Euro in the Mezzogiorno against the corresponding spending of 780 Euro in the regions of the Centre North. Therefore, on average, an inhabitant of the Mezzogiorno every year has received 12\% more compared to an inhabitant of the Centre North. ${ }^{3}$ Finally, a further element that signals the importance of the public intervention in the Mezzogiorno is represented by the size of the capital account public expenditure compared to GDP. From 1996 to 2006, the Mezzogiorno received, on average, only 38.7\% of the national capital account public expenditure, but these public transfers to the South of the country represent a quota $(6.2 \%)$ of GDP that is double that $(3.1 \%)$ observed for the regions of the Centre North (table 1$) .4$

Table 1 Territorial distribution of public investments (average values 1996-2006, constant prices 2000)

\begin{tabular}{lccccc} 
& Population & GDP & $\begin{array}{l}\text { Capital } \\
\text { account } \\
\text { expenditure }\end{array}$ & $\begin{array}{l}\text { Capital } \\
\text { account } \\
\text { expenditure } \\
\text { /Pop }\end{array}$ & $\begin{array}{l}\text { Capital } \\
\text { account } \\
\text { expenditure } \\
\text { /GDP }\end{array}$ \\
\hline Centre-North & 64,2 & 75,9 & 61,3 & 780 & 3,1 \\
Mezzogiorno & 35,9 & 24,1 & 38,7 & 876 & 6,2 \\
Italy & 100 & 100 & 100 & 815 & 3,9 \\
\hline
\end{tabular}

Source: own elaboration from data of the Italian National Institute of Statistics (ISTAT 2005, 2008) and "Regional Public Accounts" dataset, Department for Development and Cohesion Policies of the Italian Ministry of Economic Development (2008)

A substantial support to the development of the Mezzogiorno has been offered by the EU resources coming from the Structural Funds and from the national co-financing. ${ }^{5}$ Although it is not possible to separate the financing by source, we know that the EU funds have represented a large quota of the overall capital account public expenditure received by the Mezzogiorno (Ministry of Economic Development, 2008). The Structural Funds area distribution is reported in table 2, which shows the resources channelled to Italian regions. Data are expressed in absolute terms or as share of GDP, population and regional investments. ${ }^{6}$

3 The analysis of the data should consider the internal composition of the capital account public expenditure, since the expenditure for investments, rather than transfers, is the one that mainly stimulates the territorial rebalancing. In reality, the capital account transfers are greater in the Mezzogiorno in comparison to the Centre North, while an inverse relationship is observed for the investments expenditure.

${ }^{4}$ If the greater public sector is considered, or rather if there were also included in the analysis, besides the Public Administration, the national and local public enterprises, a greater concentration of the capital account public expenditure would be seen in the regions of the Centre North. This result is due to the greater presence of public enterprises in this area of the country.

${ }^{5}$ The regional policy in Italy is financed, other that from the EU resources (Structural Funds and national co-financing), from those of the Fund for Under-Utilized Areas that should allocate $85 \%$ of its resources to the Mezzogiorno.

6 The data on the Structural Funds are drawn from the Italian Authority for Monitoring (IGRUE) and annual reports by the Italian Ministry of Economy and Finance (1996 - 2007) and are available only beginning from 1996. They refer to the total resources invested without making any distinction between the quota disbursed by the European Union, by the national State and by the private entities. The multiregional funds have been divided in equal parts among the regions. Finally, we do not consider the expenditure for programmes of Technical Assistance and for the Community Initiatives and the 
Over the period considered, the amount of Structural Funds received by Italy was more than 110 billion Euro (almost 78 billion in the regions of the Mezzogiorno and a little more than 32 billion in those of the Centre-North). In the Mezzogiorno of Italy these transfers represent around $11 \%$ of the total investments and $40 \%$ of public investments, while in the Centre-North they equal, respectively, $1.4 \%$ and $9.5 \%$. A first conclusion that can be drawn from this data is that the distribution of Structural Funds thus favours the backward areas of the country signalling a strong dependence of these economies on the investments activated by Europe.

Table 2 Territorial distribution of structural funds

\begin{tabular}{|c|c|c|c|c|c|c|c|}
\hline & $\begin{array}{c}\text { Programmin } \\
\text { g Periods } \\
1994-1999\end{array}$ & $\begin{array}{l}\text { Programmin } \\
\text { g Periods } \\
2000-2006\end{array}$ & $\begin{array}{l}1994- \\
2006\end{array}$ & $\begin{array}{c}\text { SF/GD } \\
\mathbf{P}\end{array}$ & $\begin{array}{c}\text { SF/Po } \\
\mathbf{p}\end{array}$ & $\begin{array}{c}\text { SFI Total } \\
\text { Invesmen } \\
t\end{array}$ & $\begin{array}{c}\text { SF/Public } \\
\text { Investmen } \\
t\end{array}$ \\
\hline \multirow{3}{*}{ Mezzogiorno: } & & & $77.838,3$ & 2,2 & 211,0 & 10,7 & 39,9 \\
\hline & $31.818,99$ & $46.019,33$ & 2 & & & & \\
\hline & & & $32.476,6$ & 0,3 & 156,6 & 1,4 & 9,5 \\
\hline Centre-North & $16.196,43$ & $16.280,25$ & 8 & & & & \\
\hline Italy & $48.015,42$ & $62.299,58$ & 110.315 & 0,7 & 191,4 & 3,6 & 20,5 \\
\hline
\end{tabular}

Source: own elaboration from data the Italian Ministry of Economy and Finance (1996-2007), The Italian National In stitute of Statistics (ISTAT 2005, 2008) and "Regional Public Accounts" dataset, Department for Development and Cohesion Policies of the Italian Ministry of Economic Development (2008)

\subsection{Managing structural funds: quantity versus quality}

For the EU policies to be effective, it is necessary that the programmed expenditure be fully absorbed by the single regions and that the programmes are put into force in an efficient way.

A representation of the financial realisation of the interventions is described in figure 1, in which the regional performances in using the Structural Funds are compared in the two programming cycles. The graphs show the ratio between the committed resources and the total amount of the programme (A/TC) and the ratio between the payments made and the total amount of the programme $(\mathrm{P} / \mathrm{TC})$.

Innovative Actions, since they do not have a regional character. Furthermore, they represent a minimal quota of the total funds (little more than 6 billion Euro in the two programming periods 1994-1999 and 2000-2006). 
Figure 1 Managing structural funds programming periods 1994-99 and 2000-06
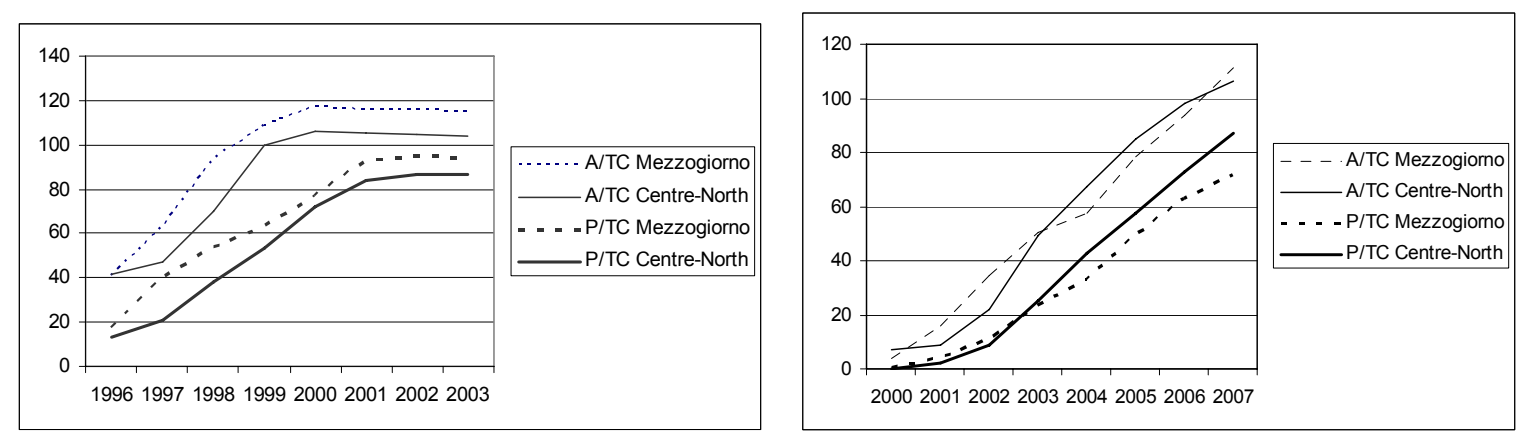

Source: own elaboration from data the Italian Ministry of Economy and Finance (1996-2007

Concerning the period 1994-1999, it is necessary to underline that the start of the programming was slow, so that by the end of 1996, namely three years after the start, only $41 \%$ of the programme had been committed and only $16 \%$ was spent. Subsequently, the payments increased because at the end of the cycle the expenditure should have reached $100 \%$ in 2001 , although, in reality, the percentage of payments was $89.7 \%$ in 2001 and $91.7 \%$ in 2003. In other words, at the end of 2003, 44,029 million Euro of the 48,015 million available had been paid. Again, in the years under scrutiny (1994-1999) there are substantial territorial differences in managing the Structural Funds. This is signalled by the fact that the ratios A/TC and P/TC are $115 \%$ and $94 \%$ when considering the Mezzogiorno, while the corresponding values are $104 \%$ and $87 \%$ in the Centre-North. ${ }^{7}$

Figure 1 shows that in the programming cycle 2000-2006, the Centre-North had a contained growth of the commitments and the payments in the first two years, that is an evident signal of the difficulties met in the start of the programme. Once the initial phase had been overcome, all the indices show a better performance for the Centre-North compared to the Mezzogiorno. From a general point of view, at the end of 2007 all the available resources had been committed in the Mezzogiorno and in the Centre-north, while the payments effected by $31 / 12 / 2007$ amount to almost $82 \%$ of the total programme $(72 \%$ in the Mezzogiorno and $87 \%$ in the Centre North) and to $74 \%$ of the committed resources ( $72 \%$ in the Mezzogiorno and $82 \%$ in the Centre North). These figures will improve as the formal closing of the cycle 2000-2006 has been fixed for 30/06/2009.

An important indication from of these results is the link between the ability to manage the Structural Funds and their impact on the regional economies. It is evident that a necessary condition, even if not a sufficient condition, for a policy to be fully effective is that the

\footnotetext{
${ }^{7}$ From the macro-area data it is not possible to fully gather the interregional differences in terms of management and use of the EU resources. In fact, the most satisfactory results achieved in the Mezzogiorno in the 1994-1999 cycle must be appraised with caution, since they depend on the good performance of four regions out of eight of the southern area of the country (Abruzzo, Basilicata, Molise and Sardinia) and from the low spending ability of five regions of the Centre-North (Lazio, Marche, Piedmont, Umbria and Veneto). Besides that, it is necessary to underline that only 8 regions (Trentino Alto Adige, Friuli Venezia Giulia, Toscana, Valle d'Aosta, Abruzzo, Basilicata and Sardinia) have used all of the programmed funds and of these only 2 (Basilicata and Sardinia) belong to the southern area of the country. For a separate analysis at a regional level see Aiello and Pupo (2009).
} 
anticipated spending be used. The preceding analysis indicates that not all the resources have been used and that there was a concentration of spending in the three year period 2000-03, a period that is too recent for the spending to have exerted all of its effects.

Irrespective of the way in which the spending was managed, it is useful to remember that the resources assigned to the Mezzogiorno are greater than those for the regions of the CentreNorth. As shown in table 2, this is true in absolute terms and in relative terms (in comparison to GDP, population and investments) and, therefore, it could be expected that, all other things being equal, the final impact of the European cohesion policy would be greater in the South of Italy.

In reality, the matter of the quantity of the spending cannot be separated from the problem of the quality of how the money is spent. This aspect, however, cannot fully be covered in this study. Nevertheless, three considerations can be made.

The first one concerns the procedure used to report the expenses made as national cofinancing. The EU rules establish that a part of the programmes be financed by the member state that receives the EU help and that such spending is additional in comparison to that already planned by the ordinary regional policies of each member state. It can be noted, instead, that the majority of this co-financed expenditure concerns interventions already undertaken (the so called "side-projects") and, therefore, concerns projects which in many cases are very far from the development strategies indicated in the general programmes funded by the EU.

The second observation concerns the operating rules to assign the resources. The implemented mechanisms exclude any form of competition between regions concerning the proposed projects. Therefore, the regional authorities do not have any incentive to use the Structural Funds to realise high productive projects and, in so doing, their action may create problems both of moral hazard and rent seeking.

The third consideration refers to the idea that the simple incentive of the spending can guarantee results in terms of effectiveness of the policies. In reality, the attainment of determined levels of expenditure, imposed by the EU rules, has come to represent an objective in itself for the regions rather than the means to achieve the objectives of the regional policies. Because each region had to record a high level of expenditure, whatever the project, this mechanism has caused continuous reprogramming with the consequence that at the end of the process the final interventions are disjointed and different from those initially programmed.

These observations lead to some remarks on the importance of the quality of the expenditure, rather than on the quantity of the disbursed financing. If the EU funds are not properly spent, instead of accelerating the regional convergence, they can reduce the free action of market forces which are the source of economic growth. This is highly likely to occur when the non-productive EU expenditure decreases, for example, the labour mobility or crowds-out the private investments.

\section{EU structural support and regional growth}

\subsection{The empirical framework}

The previous sections indicated that EU programmes have been a meaningful source of financing for the regional policies activated in Italy during the last 20 years. Alongside the evaluations on the management of the funds, it is extremely useful to evaluate the effect of these policies on the economic growth of Italian regions. 
From an analytical point of view, the main approach to study the reduction of regional discrepancies has been the analysis of convergence, according to which the income of the poorest regions converges, in the long run, toward that of the richest regions (Solow, 1956). The presence of convergence can be verified through a growth equation aimed at assessing the existence of a negative relationship between the initial level of GDP per-capita and its growth rate ( $\beta$-convergence).

In this article we use a model in which the annual growth rates of GDP per-capita are conditioned, other than from the initial level of GDP per-capita and from the growth determinants in the Solow equation, from the expenditure of Structural Funds effectively made by each region in the years 1996-2007.

The choice to limit the analysis to the period 1996-2007 is due to the existence of a misspecification bias of the model occurring if we considered a longer time period. ${ }^{8}$ Furthermore, we try to overcome the bias related to the size of the sample because the estimates have been made by using annual data9. Nevertheless, this choice, if on one hand determines an increase of the dimension of the panel, on the other hand, it introduces a business-cycle effect which it is necessary to control for in the estimation. To do this, the following general error correction model is considered: 10

$$
\begin{aligned}
\ln \left(y_{i t}\right) & =\beta \ln \left(y_{i, t-1}\right)+\gamma \ln \left(s_{i t}\right)+\phi \ln \left(n_{i t}+g+\delta\right)+\alpha \ln \left(h_{i t}\right)+\theta \ln \left(f_{i t}\right)+\mu_{i}+\eta_{t}+ \\
& +\pi_{1} \Delta \ln \left(s_{i t}\right)+\pi_{2} \Delta \ln \left(h_{i t}\right)+\pi_{3} \Delta \ln \left(n_{i t}\right)+\pi_{4} \Delta \ln \left(f_{i t}\right)+\varepsilon_{i t}
\end{aligned}
$$

in which $\mathrm{T}=1996,1997, \ldots . .2007, y_{i t}$ is the GDP per-capita of the region $i$ at the time $t, y_{i t-1}$ is the GDP per-capita in the year $\mathrm{t}-1, \mathrm{~s}_{\mathrm{it}}$ is the ratio investments/GDP of region $i$ at the time $\mathrm{t}, n_{i t}$ is the growth rate of population, $g$ indicates the growth rate of the exogenous technical progress, $\delta$ represents the depreciation rate of physical capital, while $h_{\text {it }}$ is an indicator of human capital. The variable $f_{\text {it }}$ indicates the Structural Funds, expressed as share of regional GDP, spent by region $i$ in the year $t$. The variable $\eta_{t}$ is time fixed effect to control for any macroeconomic

8 In fact, if a longer period were considered, one would attribute a value (i.e., zero) to the vector of regional Structural Funds in the period preceding 1996, when, in reality, this is missing data. This error produces distorted and not efficient estimates if, for example, the growth rates are higher before 1996 because of some unobserved variable. In effect, since the growth rate of productivity in Italy decreases around the mid 1990s, if a longer period were considered, one would obtain an underestimation of the parameter associated to the Structural Funds.

9 In the literature, the choice to consider annual data to estimate growth equations à la Solow is followed, among the others, by Benos and Karagiannis (2008), Lanzafame (2005), Lee et al (1998), Loddo (2006) and Presbitero (2005). The use of annual data is also linked to the impossibility to divide the years from 1996 to 2007 in sub-periods, as was effected, for the case of the Italian regions by Carmeci and Mauro (2002), Di Liberto et al., (2007) and Aiello and Scoppa (2006). In fact, also considering three year intervals, only four observations would be obtained for each region (1996-98; 1999-01; 2002-04, 2005$07)$.

${ }^{10}$ The specification of the error correction model used in this paper is that proposed by Arnold, Bassanini and Scarpetta (2007) that uses the annual data of the OECD countries from 1971 to 2004 to compare the models of Lucas and Solow (see also Brauninger and Pannenberg, 2002). 
shocks that affect everyone uniformly, while $\mu_{i}$ is the regional fixed effect to control for nonobservable regional heterogeneity. Finally, $\varepsilon_{i t}$ represents the random error term. ${ }^{11}$

The equation [1] has been estimated using as dependent variable not only the GDP percapita, but also labour productivity.

\subsection{Results}

This section focuses on the results obtained when estimating the equation [1] with the GMM-SYS method and the LSDV estimator, as corrected by Kiviet (1995) (henceforth LSDVC). ${ }^{12}$

The estimates are reported in table 3. The first four columns present the outcome obtained considering the GDP per-capita as dependent variable, while in the estimates summarised in the last four columns the focus is on the labour productivity. Columns 1 and 3 report the results obtained with the LSDVC and GMM-SYS methods, while columns 2 and 4 concern the results that are obtained when the estimates are replicated when the growth model is augmented with the dummy variable "South." The same structure is used as far as the labour productivity results are concerned.

A first outcome is that, as expected, there is both a positive impact of human capital on regional growth, and a negative effect of the variables that determine the balanced growth. The coefficient of the private investments ${ }^{13}$ is positive and statistically significant, although the

${ }^{11}$ The historical series of the variables of interest have been constructed using the annual data of the regional economic accounts (ISTAT 2005; 2008). The variables $y_{i t}$ and $s_{i t}$ are expressed in constant 2000 prices. The rate of technical progress $(g)$ and the depreciation rate $(\delta)$ are hypothesised as equal among the regions and constant over time. The variable $g$ corresponds to the average annual growth rate of the productivity of labour observed in Italy in the considered period and it equals $1.38 \%$. The variable $\delta$ is given by the geometric mean of the ratio "Depreciation of the capital /Capital Stock" observed in Italy in the analysed period and it equals $4.21 \%$. The variable $h_{\mathrm{i}}$ is obtained following the approach of

Mincer (1974) and it equals $h_{i}=e^{r_{i} S_{i}}$, where $S_{i}$, is the average level of schooling in every region and $r_{i}$ is the rate of return of education, the values of which are those estimated for every region by Ciccone (2004). The average schooling ( $\mathrm{Si}$ ) of the labour force of the i-th region is, therefore, a weighted average of the years of schooling of the labour force, the weights of which are the relative frequencies of the labour force by degree of education (Quarterly Surveys of the work forces, ISTAT).

${ }^{12}$ The regional fixed effects introduce correlation between a regressor and the error term. In such a case, the speed of convergence is underestimated and, if all regressors are strictly exogenous, this bias that can be corrected using a fixed effect model. However, if such an assumption is not valid, then the fixed effect estimators produce inconsistent estimates and the solution is to use the instrumental variables and GMM methods (Anderson and Hsiao, 1982; Arellano and Bond, 1991; Arellano and Bover, 1995). Nevertheless, the IV-GMM estimators are efficient only asymptomatically (they are not appropriate for estimates on small samples $T \leq 10)$. In our case, as the value of $T$ is at the limit $(T=12)$ it was decided to use, together with the GMM-SYS method, the LSDV estimator corrected by Kiviet (1995) which introduces into the LSDV estimates a correction of the distortion due to the limited size of the sample [as for the advantages to use the GMM and LSDVC estimators in the case of small sample see, also, Bruno (2005) and Judson and Owen (1999)].

${ }^{13}$ Using the data of the regional economic accounts published by ISTAT, it is possible to get the private investments by subtracting from total investments those effected by the public administration and those related to health, to education and public services. 
estimated value is relatively very low. As for the specific objective of this work, the results reported in table 3 show that the sign of the coefficient $\theta$ is always positive, although the estimated value varies according to the estimator used. The minimum value $(0.081)$ is obtained in the case of the LSDVC estimator (column 1), while the maximum value (0.09) refers to the GMM-SYS estimates (column 3). These outcomes provide a quantitative evaluation of the relationship between Structural Funds and regional growth and they indicate that a variation of the per-capita EU spending, for example, of 10\% determines, on average, an increase of the GDP per-capita of about $0.9 \%$ when the GMM-SYS method is used and of about $0.81 \%$ in the case of the LSDVC estimates. ${ }^{14}$

Further indications emerge when the impact of the structural policies is separately considered in the two macro-areas of the country. These results are shown in columns 2 and 4 of table 3 and they are obtained inserting in the equations [1] the interaction variable $f_{i t} * D_{\text {sud }}$, with $\mathrm{D}_{\text {sud }}$ equal to one for the regions of the Mezzogiorno and zero for the regions of the Centre-North. The coefficient associated to the interaction variable is always positive and highly significant: with respect to the regions of the Centre-North, the differential impact of Structural Funds in the Mezzogiorno is about 0.06 (0.061 in the case of the Kiviet estimates and 0.058 for the GMMSYS estimates). This result adds a contribution to the debate on the effectiveness of the policies of territorial rebalancing, indicating that the Structural Funds play a greater role in the Mezzogiorno than that observed for the regions of the Centre-North. In some way this effect is expected and it is related to the redistribution of EU funds among the Italian regions: the poorest regions have received, on average, a greater amount of the EU payments and this has induced an increase of the annual average growth rate of GDP per-capita.

\footnotetext{
${ }^{14}$ An analogous positive link between the Structural Funds and the regional growth in Italy is obtained by Loddo (2006), in which the coefficient associated to the ratio SF/GDP is 1.11 , a value significantly higher than that obtained in this study. These differences in results can depend on the fact that, in comparison to the Loddo (2006) study, the estimators used in this work control for the small size of the sample, for the endogenous nature of the regressors and, finally, for the business-cycle effects.
} 
Table 3 The impact of Structural Funds on regional convergence in Italy. GMM-SYS and LSDVC estimates (1996-2007).

\begin{tabular}{|c|c|c|c|c|c|c|c|c|}
\hline \multirow[b]{2}{*}{ Variables } & \multicolumn{4}{|c|}{$\begin{array}{l}\text { Dependent Variable: } \\
\text { GDP per-capita (in logs) }\end{array}$} & \multicolumn{4}{|c|}{$\begin{array}{c}\text { Dependent Variable: } \\
\text { Labour Productivity (in logs) }\end{array}$} \\
\hline & $\begin{array}{l}\text { LSDVC } \\
\text { KIVIET } \\
(1) \\
\end{array}$ & $\begin{array}{l}\text { LSDVC } \\
\text { KIVIET } \\
(2) \\
\end{array}$ & $\underset{(3)}{\text { GMM-SYS }}$ & $\begin{array}{l}\text { GMM- } \\
\text { SYS } \\
(4) \\
\end{array}$ & $\begin{array}{l}\text { LSDVC } \\
\text { KIVIET } \\
(5) \\
\end{array}$ & $\begin{array}{l}\text { LSDVC } \\
\text { KIVIET } \\
(6) \\
\end{array}$ & $\begin{array}{l}\text { GMM- } \\
\text { SYS } \\
(7) \\
\end{array}$ & $\begin{array}{c}\text { GMM- } \\
\text { SYS } \\
(8) \\
\end{array}$ \\
\hline $\operatorname{Ln}\left(y_{i, t-\tau}\right)$ & $\begin{array}{l}0,9401 \\
(11.22)\end{array}$ & $\begin{array}{c}0,94 \\
(9.07)\end{array}$ & $\begin{array}{c}0,9472 \\
(2.78)\end{array}$ & $\begin{array}{l}0,947 \\
(2.56)\end{array}$ & $\begin{array}{c}0,9408 \\
(5.71)\end{array}$ & $\begin{array}{c}0,9406 \\
(5.71)\end{array}$ & $\begin{array}{l}0,95 \\
(1.98)\end{array}$ & $\begin{array}{l}0,951 \\
(2.01)\end{array}$ \\
\hline $\ln \left(\mathrm{s}_{\mathrm{i}, \mathrm{t}}\right)$ & $\begin{array}{l}2 \mathrm{E}-06 \\
(2.43)\end{array}$ & $\begin{array}{c}1,9 \mathrm{E}-06 \\
(2.16)\end{array}$ & $\begin{array}{c}0,000009 \\
(1.63)\end{array}$ & $\begin{array}{c}9 \mathrm{E}-06 \\
(1.81) \\
-\end{array}$ & $\begin{array}{l}1 \mathrm{E}-05 \\
(1.49)\end{array}$ & $\begin{array}{c}\text { 1,4E-05 } \\
(1.65)\end{array}$ & $\begin{array}{c}0,0008 \\
(1.83)\end{array}$ & $\begin{array}{c}0,0008 \\
(1.79)\end{array}$ \\
\hline $\ln \left(n_{i, t}+g+\delta\right)$ & $\begin{array}{l}-0,001 \\
(-1.56)\end{array}$ & $\begin{array}{l}-0,001 \\
(-1.78)\end{array}$ & $\begin{array}{c}-0,0136 \\
(-2.16)\end{array}$ & $\begin{array}{l}0,0136 \\
(-2.21)\end{array}$ & $\begin{array}{l}-0,004 \\
(-2.89)\end{array}$ & $\begin{array}{c}-0,004 \\
(-2.32)\end{array}$ & $\begin{array}{l}-0,071 \\
(-4.01)\end{array}$ & $\begin{array}{r}-0,071 \\
(-3.74)\end{array}$ \\
\hline $\ln \left(h_{i, t}\right)$ & $\begin{array}{l}0.197 \\
(2.43)\end{array}$ & $\begin{array}{l}0.1966 \\
(2.28)\end{array}$ & $\begin{array}{l}0,349 \\
(1.75)\end{array}$ & $\begin{array}{c}0,349 \\
(1.8)\end{array}$ & $\begin{array}{l}0.39 \\
(2)\end{array}$ & $\begin{array}{l}0.392 \\
(2.09)\end{array}$ & $\begin{array}{l}0,361 \\
(1.85)\end{array}$ & $\begin{array}{l}0,356 \\
(1.78)\end{array}$ \\
\hline $\ln \left(\mathrm{F}_{\mathrm{i}, \mathrm{t}} / \mathrm{GDP}_{\mathrm{i}, \mathrm{t}}\right)$ & $\begin{array}{l}\mathbf{0 , 0 8 1} \\
(3.01)\end{array}$ & $\begin{array}{l}0,017 \\
(2,43)\end{array}$ & $\begin{array}{c}\mathbf{0 , 0 9} \\
(2,49)\end{array}$ & $\begin{array}{l}\mathbf{0 , 0 2 9} \\
(1,98)\end{array}$ & $\begin{array}{l}0,001 \\
(1.56)\end{array}$ & $\begin{array}{c}0,00001 \\
(1.26)\end{array}$ & $\begin{array}{l}0,007 \\
(1,45)\end{array}$ & $\begin{array}{l}1 E-05 \\
(1,28)\end{array}$ \\
\hline$D_{\text {sud }}{ }^{*} \ln \left(F_{i, t} / G D P_{i, t}\right)$ & & $\begin{array}{l}\mathbf{0 , 0 6 1} \\
(3,76)\end{array}$ & & $\begin{array}{l}\mathbf{0 , 0 5 8} \\
(5,61)\end{array}$ & & $\begin{array}{c}0,0009 \\
(1.61)\end{array}$ & & $\begin{array}{c}\mathbf{0 , 0 0 3 9} \\
(1,59)\end{array}$ \\
\hline$\Delta \ln \left(\mathrm{s}_{\mathrm{i}, \mathrm{t}}\right)$ & $\begin{array}{l}3 E-07 \\
(1.47)\end{array}$ & $\begin{array}{l}3 E-07 \\
(1.01)\end{array}$ & $\begin{array}{c}9,8 E-08 \\
(1.67)\end{array}$ & $\begin{array}{l}8 E-08 \\
(1.73)\end{array}$ & $\begin{array}{l}3 E-07 \\
(1.47)\end{array}$ & $\begin{array}{c}5,4 E-07 \\
(1.4)\end{array}$ & $\begin{array}{l}2 E-08 \\
(1.58)\end{array}$ & $\begin{array}{l}3 E-08 \\
(1.66)\end{array}$ \\
\hline$\Delta \ln \left(\mathrm{n}_{\mathrm{i}, \mathrm{t}}\right)$ & $\begin{array}{l}-8 E-07 \\
(-1.51)\end{array}$ & $\begin{array}{l}-8 E-07 \\
(-1.81)\end{array}$ & $\begin{array}{c}-4,5 E-08 \\
(-1.82)\end{array}$ & $\begin{array}{c}-7 E-08 \\
(-1.8)\end{array}$ & $\begin{array}{l}-8 E-07 \\
(-1.51)\end{array}$ & $\begin{array}{l}-1 E-06 \\
(-1.35)\end{array}$ & $\begin{array}{l}-5 E-08 \\
(-1.92)\end{array}$ & $\begin{array}{l}-8 E-08 \\
(-1.96)\end{array}$ \\
\hline$\Delta \ln \left(\mathrm{h}_{\mathrm{i}, \mathrm{t}}\right)$ & $\begin{array}{c}0,00005 \\
(0.5)\end{array}$ & $\begin{array}{c}0,00005 \\
(1.01)\end{array}$ & $\begin{array}{l}2 E-07 \\
(1.14)\end{array}$ & $\begin{array}{l}2 E-07 \\
(1.22)\end{array}$ & $\begin{array}{l}5 E-05 \\
(0.32)\end{array}$ & $\begin{array}{c}7,1 E-05 \\
(0.75)\end{array}$ & $\begin{array}{l}2 E-06 \\
(1.321)\end{array}$ & $\begin{array}{l}2 E-06 \\
(1.39)\end{array}$ \\
\hline$\Delta \ln \left(\mathrm{F}_{\mathrm{i}, \mathrm{t}} / \mathrm{GDP}_{\mathrm{i}, \mathrm{t}}\right)$ & $\begin{array}{c}0,00002 \\
(1.5)\end{array}$ & $\begin{array}{c}0,00002 \\
(1.54)\end{array}$ & $\begin{array}{c}4,38 E-06 \\
(1.12)\end{array}$ & $\begin{array}{l}5 E-06 \\
(1.34)\end{array}$ & $\begin{array}{c}0,0003 \\
(1.11)\end{array}$ & $\begin{array}{c}0,00002 \\
(1.31)\end{array}$ & $\begin{array}{l}8 E-06 \\
(1.46)\end{array}$ & $\begin{array}{l}8 E-06 \\
(-1.8)\end{array}$ \\
\hline Sargan Test ( $p$-value) & & & 0,49 & 0,49 & & & 0,51 & 0,51 \\
\hline$A R(1)(p$-value $)$ & & & 0.02 & 0.02 & & & 0.07 & 0.068 \\
\hline AR(2) (p-value) & & & 0.53 & 0.495 & & & 0.61 & 0.592 \\
\hline Obs. & 220 & 220 & 220 & 220 & 220 & 220 & 220 & 220 \\
\hline Speed of Convergence & $6,18 \%$ & $6,19 \%$ & $5,42 \%$ & $5,45 \%$ & $6,10 \%$ & $6,12 \%$ & $5,13 \%$ & $5,02 \%$ \\
\hline
\end{tabular}

Note: In brackets we report the heteroskedasticity-robust t-student statistics, expect in Kiviet where the $z$ statistics is from 100 bootstrap iterations. In GMM-SYS estimates all regressors are endogenous and are instrumented by all available lags. All regressions include time and regional fixed effects.

Finally, the effects of the Structural Funds on the labour-productivity convergence are reported in the last four columns of table 3 . We find that in all the estimated models the coefficient associated to variable $f_{\text {it }}$ is not economically interpretable, because of its low significance. Analogous results are obtained when the variable interaction $f_{i t}{ }^{*} D_{\text {sud }}$ is considered. 


\section{Discussion and concluding remarks}

This paper shows that the distribution of EU funds is coherent with the criterion to attribute greater resources to the less developed regions: in Italy the payments assigned to the Mezzogiorno are greater than those received by the regions of the Centre-North of the country.

Another key issue that we find is that the capacity to manage the funds between the two macro-areas of the country differs according to the programming period. Nevertheless, if the behaviours of the single regions are considered, it is observed how the performance in the use of EU resources is linked to the ability of the individual regional administrations at that time more than the territory involved. A common fact is that not all the resources have been employed and that there was a concentration of the spending in the years 2000-03, which is a period relatively too recent for the public expenditure to have been able to produce all of its effects.

The key result which comes from the econometric analysis is that of obtaining a quantitative evaluation of the relationship between Structural Funds and convergence in Italy and territorial areas. As far as the GDP per-capita convergence is concerned, the impact of EU support is found to be positive, although its magnitude is extremely low. When considering the territorial effects of the EU spending, it is observed that the impact on GDP per-capita growth is slightly greater in the Mezzogiorno. On the contrary, we find that the EU funds do not impact on the labour-productivity convergence, whatever the area.

All these results lead to various issues.

The first question refers to one of the pre-requisites for the Structural Funds to be effective. Indeed, any EU funded project is only conditionally effective, in the sense it may be effective in stimulating (catching-up) growth only if the institutions of the supported regions are of a sufficient quality. There is a lot of evidence showing that central and peripheral institutions in Italy work in a very slow complex way and in many cases they may pursue objectives other than those related to development (Profeti 2006).

A second well-documented point is that the measures adopted by the EU to improve the management of the funds overrate the quantity rather than the quality of the spending. Put in other words, the beneficiary regions are often in a race to spend a large amount of EU transfers and, sometimes, they pay too little attention to the quality of the funded projects, in the sense that even the initiatives with a very low productive impact have been admitted. This is also why the mechanics of the EU procedures often force the regional institutions to report the payments made within a given period, whatever the project.

Bearing in mind the above mentioned dilemma of "quantity versus quality", it is worth noticing that the EU funds may replace other convergence mechanisms such us, for instance, labour mobility. This holds particularly true in the backward Italian regions, where the EU funds are also seen as an additional window at which to claim for assistance, whatever the economic relevance of the funded project. An interesting case supporting this view is given by the myriad of projects oriented to train labour forces in sectors which are either totally marginal with respect to the structural constraints that hinder the economic growth of southern regions or of a limited impact provided that they produce goods for local markets. Similar arguments may be made for the mass of production-oriented projects, even in dynamic sectors, which few years after getting the finance do not put the business on its feet and therefore do not fulfil the initial promises to be productive. Again, a further crowding-out effect exists when the EU resource is used to finance projects that are close substitutes for private capital. In our empirical framework we pick up these impacts in the GDP per-capita regressions (the resources to finance the projects increase, in same 
way, the income of beneficiaries), but we do not in the labour-productive regressions, basically because many initiatives are "in-sé e per-sé" far from affecting the regional productivity.

From the above discussion it is right to argue that the question related to the effectiveness of the Structural Funds arises as to whether the money devoted to regional development has been spent on the most appropriate objectives. Besides the previous examples related to the policies which improve the quality of human capital or directly aid the firms, in Italy a large share of the EU expenditure is for infrastructure. In this respect, our results concerning the relatively greater effectiveness of Structural Funds in the Mezzogiorno could be explained with reference to the results of the works of Bonaglia et al. (2000), Destefanis and Sena (2005), Marrocu and Paci (2008) and Picci (1999), in which they show a greater impact on the core infrastructure in the South of Italy. However, it must be noted that the divide between the regions has not changed over time and, therefore, even if the increase of the infrastructure endowment has contributed to determine a greater impact of the spending in the Mezzogiorno, it is evident that the European cohesion policy has not fully reached the set objective, that is to reduce the disparities inside each member state (European Commission, 2001; 2007).

It is reasonable to think, instead, that the increase of the average rate of growth of the percapita income in the South of Italy is simply determined by the European transfers that have mostly interested the southern area of the country. Therefore, what could appear at first as a positive signal for the solution of the problem of the dependence of the southern economy on external resources is nothing more than the result of that same dependence: the income in the north of the country increases because the north produces income while the income in the south of the country increases mainly because of external transfers/funding.

The reading of these results leads us to conclude that the Structural Funds have not modified the structural conditions that determine the long term growth of the Italian regions and, therefore, have only slightly contributed to resolve the problem of the north-south divide. 


\section{References}

Aiello F. - Pupo V. (2009), L'impatto della politica regionale dell'Unione Europea. Uno studio sulle regioni italiane. Rivista Italiana degli Economisti, (forthcoming).

Aiello F. - Scoppa V. (2006), Convergence and Regional Productivity Divide in Italy: Evidence from Panel Data, Papers of XXVII Italian Conference of Regional Science, Pisa 12/14 October 2006 ISBN 88-87788-07-3.

Anderson T.W. - Hsiao C. (1982), Formulation and Estimation of Dynamic Models using Panel Data, Journal of Econometrics, 18, pp. 47-82.

Arnold J. - Bassanini A. - Scarpetta S. (2007), Solow or Lucas? Testing Growth Models using Panel Data from OECD Country, OECD, ECO/WKP(2007)52.

Arellano M. - Bond S. (1991), Some Tests of Specification for Panel Data: Monte Carlo Evidence and an Application to Employment Equations, Review of Economic Studies, 58, pp. 277-297.

Arellano M. - Bover O. (1995), Another Look at the Instrumental Variables Estimation of Error Component Models, Journal of Econometrics, 68 (1), pp. 29-52.

Benos N. - Karagiannis S. (2008) Convergence and Economic Performance in Greece: Evidence at Regional and Prefecture Level, RURDS, 20, 1, pp 52-69.

Boldrin M. - Canova F. (2001), Inequality and Convergence: Reconsidering European Regional Policies, Economic Policy, 32, pp. 207-53.

Bonaglia F. - La Ferrara E. - Marcellino M. (2000), Public Capital and Economic Performance: Evidence from Italy, Giornale degli Economisti e Annali di Economia, 59, pp. 221-244.

Brauninger M. - Pannenberg M., (2002), Unemployment and Productivity Growth: an Empirical Analysis Within an Augmented Solow Model, Economic Modelling, 19, pp. 105-120.

Bruno G. S. F. (2005), Approximating the Bias of the LSDV estimator for Dynamic Unbalanced Panel Data Models, Economics Letters, 87, pp. 361-366.

Cappelen A. - Castellaci F. - Fagerberg J. - Verspagen B. (2003), The impact of regional support on growth and convergence in the European Union, Journal of Common Market Studies, 41 (4), pp.621-644.

Carmeci G. - Mauro L. (2002), The Convergence of the Italian Regions and Unemployment. Theory and Evidence, Journal of Regional Science, 42 (3),

Ciccone A (2004), Human Capital as a Factor of Growth and Employment at the Regional Level: The Case of Italy, Universitat Pompeu Fabra, Barcelona.

Coppola G. - Destefanis S. (2007), Fondi strutturali, produttività e occupazione. Uno studio sulle regioni italiane, Rivista di economia e statistica del territorio, 2, pp. 191-212. 
De la Fuente A. (2002), The effect of structural on the Spanish Regions: an Assessment of the 1994-1999 Objective 1 CSF, CERP Discussion Paper, n. 3673.

Dall'erba S. - Le Gallo J. (2008), Regional Convergence and the Impact of European Structural Funds over 1989-1999: a Spatial Econometric Analysis, Papers in Regional Science, 87 (2), pp.219-244.

Destefanis S. - Sena V., (2005) Public capital and total factor productivity: New evidence from the Italian regions, 1970-98, Regional Studies, 39, 5, pp. 603-617.

Di Liberto A. - Pigliaru F. - Mura R., (2007) How to Measure the Unobservable. A Panel Technique for the analysis of TFP Convergence, Oxford Economic Papers, 59, pp. 1-26.

Ederveen S. - Gorter J. - de Mooij R. - Nahuis R. (2002), Funds and Games: The Economics of European Cohesion Policy, CPB Netherlands' Bureau for Economic Policy Analysis, The Hague.

European Commission (2001), Unity, solidarity, diversity for Europe, its people and its territory Second report on economic and social cohesion, January 2001.

European Commission (2007), Growing Regions, growing Europe. Fourth report on economic and social cohesion, May, ISDN 92-79-05710-6, Brussels.

Garcia-Solanes J. - Maria-Dolores R. ( 2002), The impact of European Structural Funds on economic convergence in European countries and regions, in W. Meeusen and $\mathrm{J}$. Villaverde (Eds. by), Convergence Issues in the European Union, Edward Elgar, Cheltenham, Glos, pp. 334- 358.

ISAE (2001), Rapporto annuale sullo stato dell'Unione Europea, Rome.

ISTAT (2008), Conti Economici Regionali, 2000-2007, Rome.

ISTAT (2005), Conti Economici Regionali, 1980-2004, Rome.

Judson R.A. - Owen A.L. (1999), Estimating Dynamic Panel Data Models: a Guide for Macroeconomists, Economics Letters, 65, pp. 9-15.

Kiviet J.F. (1995), On Bias, Inconsistency and Inefficiency of Various Estimators in Dynamic Panel Data Models, Journal of Econometrics, 68, pp. 53-78.

Lanzafame M. (2005), Economic Structure, Technology Diffusion and Convergence: the Case of the Italian Regions, ERSA - 45a Annual Conference, Amsterdam, 23-27 August 2005.

Lee M. - Lonmire R. - Matyas L. - Harris M. (1998), Growth Convergence: some Panel Data Evidence, Applied Economics, 30, pp. 907-912.

Loddo S. (2006), Structural Funds and Regional Convergence in Italy, Working Paper CRENoS, n.3, University of Cagliari.

Marrocu E. - Paci R. (2008), The effects of public capital on the productivity of the Italian regions, Applied Economics, 1, pp.1-14 
Midelfart-Knarvik K. - Overman H. (2002), Delocation and European integration. Is structural spending justified?, Economic Policy: A European Forum, 35, pp. 321-359.

Mincer J. (1974), Schooling, Experience, and Earnings, Columbia University Press, New York.

Ministry of Economy and Finance, 1996 - 2007, Le politiche strutturali dell'Unione Europea L'attuazione in Italia. Relazione Annuale, Rome.

Ministry of Economic Development, Department for Development and Cohesion Policies (2008), Rapporto Annuale 2007, Rome.

Percoco M. (2005), The Impact of Structural Funds on the Italian Mezzogiorno, Région ed Développement, 21, pp. 141-153.

Picci L. (1999), Productivity and infrastructure in the Italian regions, Giornale degli Economisti $e$ Annali di Economia, 58, pp. 329-353.

Presbitero A.F. (2005), The Debt-Growth Nexus: a Dynamic Panel Data Estimation, Quaderno di Ricerca n. 243, Department of Economics, University of Marche.

Profeti S. (2006), La sfida europea delle regioni italiane. Quattro strategie a confronto, Rivista Italiana di Politiche Pubbliche, 1, pp. 39-69.

Puigcerver-Peňalver M.C. (2007), The Impact of Structural Funds Policy on European Regions' Growth. A Theoretical and Empirical Approach, The European Journal of Comparative Economics, 4 (2), pp. 179-208.

Pupo V. (2004), L'impatto dei fondi Strutturali: una rassegna della letteratura, Rivista Economica del Mezzogiorno, 1-2, pp. 105-131.

Solow R. M. (1956), A Contribution to the Theory of Economic Growth, Quarterly Journal of Economics, 70, pp.65-94. 